\title{
Ecological Consequences of Mechanization of the Wood Skidding Works in Greece
}

\author{
Evaggelos Karagiannis and Ploutarchos Kararizos \\ Department of Forest Engineering and Surveying, School of Forestry and Natural Environment, Aristotle University of Thessaloniki, \\ Thessaloniki 54124, Greece
}

Received: October 25, 2011 / Accepted: December 21, 2011 / Published: April 20, 2012.

\begin{abstract}
The movement of the wood skidding means on the natural ground causes damages in the soil and in the remaining stand, the size of which depends on the kind, the resistance and the soil conditions, from the size and movements frequency on the machines as well as from the length of the skidding wood. This study was carried out in a productive forest of Greece, the resistance of the soil in connection with the moisture and the category of the native stone, the pressure that tires of tractors exert in the soil, are estimated. It also estimated the percentage of the trees in the remaining stand which suffer damages from the movement of various means. The above means are used for the skidding of wood of different lengths. According to the results of the research some measures are suggested so as to decrease the damages, which are caused in the soil and in the remaining stand.
\end{abstract}

Key words: Skidding of wood, resistance of natural soil, pass ability of natural soils, damages of the natural soils, damages in the remaining stand.

\section{Introduction}

Natural forest ecosystems are regarded as dynamic, full of life with various interactions between theirs elements. These interactions partly define the steady evolution in place and in time [1].

A basic element of a production model is the damages which initially come from the technical systems regarding the cultivation and the fruition of the forest. These damages relate to each ecosystem separately, but mainly can be caused in the soil and the remaining stand. Moreover, damages can be generally related to the environment, e.g. fuels, fertilizers, noise or machine's fuels [2].

In reference to the general discussion at the end of 1960 s to the beginning of 1970 s, it was about the negative effects of technical systems. The idea of searching the damages of the wood's skidding was conceived. In 1996, Heinimann [3] gave an image of

Corresponding author: Evaggelos Karagiannis, assistant professor, main research fields: forest opening-up and wood transportation. E-mail: eakarag@for.auth.gr. the areas where the researches were carried out. According to the Canadian classification, $40 \%$ of the researches are occupied with the effects on the soil, about $25 \%$ with the effects on the remaining stand, about $20 \%$ with the effects on the water's diet, $15 \%$ with the effects on the fauna and flora and the rest are occupied with the social effects.

The damages, which are caused by the utilization of the wood's skidding machines, are the following [4-6]:

- Damages to the soil's surface because of the machine's movement and the wood's skidding which result in the soil erosion;

- Condensation of the soil due to the machine's movement (the water of the soil and its air are displaced) and therefore the decrease of the ability of the water filtration in the soil, decrease of water movement in the ground and also diminution of the soil ventilation in the horizontal direction;

- Injuries to the root system of the standing trees due to the machine's movement and therefore the decrease of the stability of the remaining stand and its attack from 
fungus and insects (effects on stand's production mainly, where cultivating lumbering takes place);

- Mechanical injury to the upper part of standing trees (as bark injury, break of branches or of an entire tree, tree's dropping and its attack by illnesses) which can be caused by machine's movement, cutting wood and tuck skidding.

In this study, it did the researches in a productive forest of Greece of the damages caused by a variety of means for the wood skidding to the soil and the remaining stand.

\section{Materials and Methods}

\subsection{Materials}

The research territory was the public forest district of Samarina (mountain range North Pindos), Prefecture of Grevena and specifically the stands $4 \mathrm{e}, 13 \mathrm{~h}, 25 \mathrm{a}$ and

\section{7d (Figs. 1 and 2).}

To achieve the research purposes, the following were used:

(1) data of the forest service in Grevena for the wood which was skidded with various means;

(2) an administrative map of the district on a scale of $1: 20,000$, as well as a geological map on a scale of 1:50,000;

(3) a portable penetrometer FARNELL (Fig. 3);

(4) a portable hygrometer GANN (Fig. 4);

(5) local measurements in the summer and autumn 2008 , with a variety of means during the performance of pine (Pinus nigra) wood skidding works, in the cluster $27 \mathrm{~d}$. The total volume of logs resulted from the logging of the wood in the research area was recorded during receipt, and it was found to be $317 \operatorname{logs}$ with a total volume of $120.48 \mathrm{~m}^{3}$.

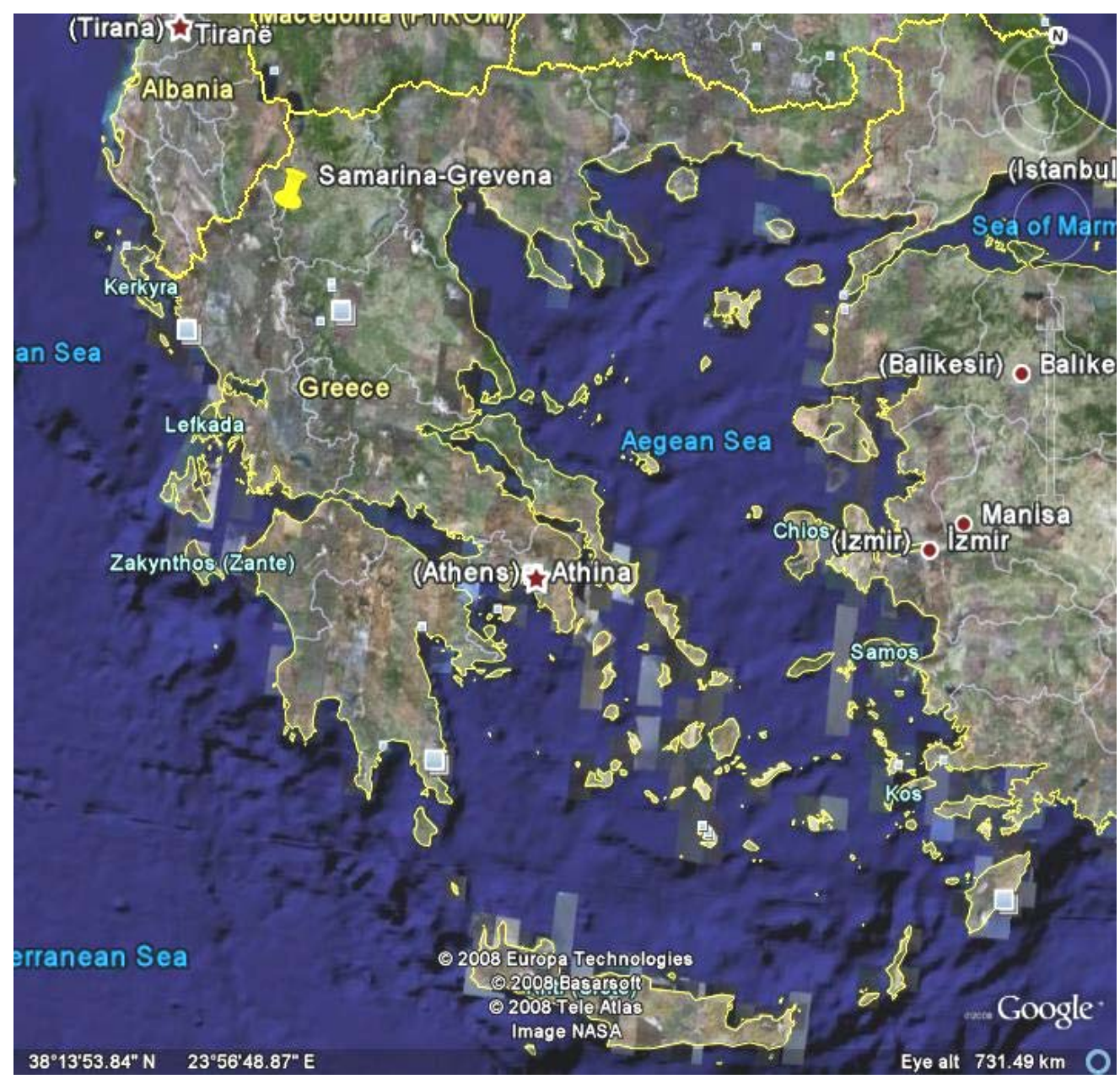

Fig. 1 Map of research area [7]. 


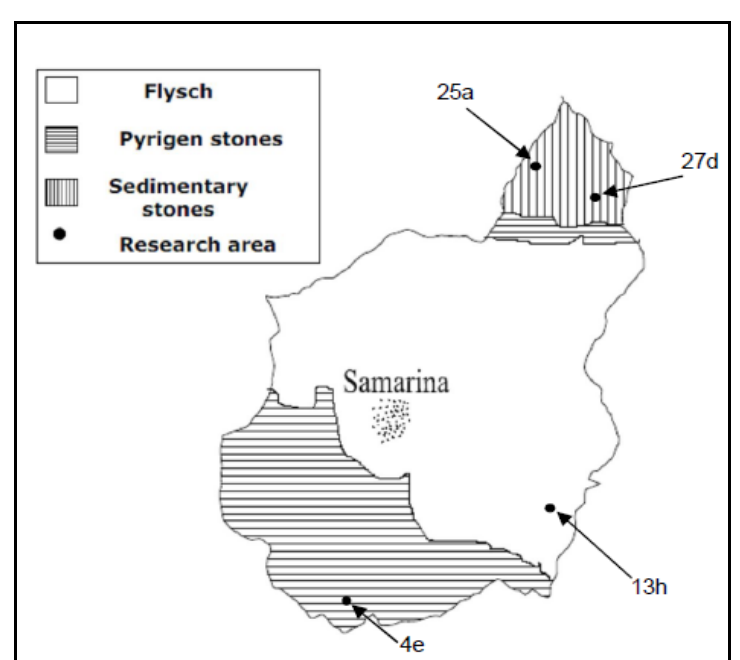

Fig. 2 Research area in the public forest district of Samarina.

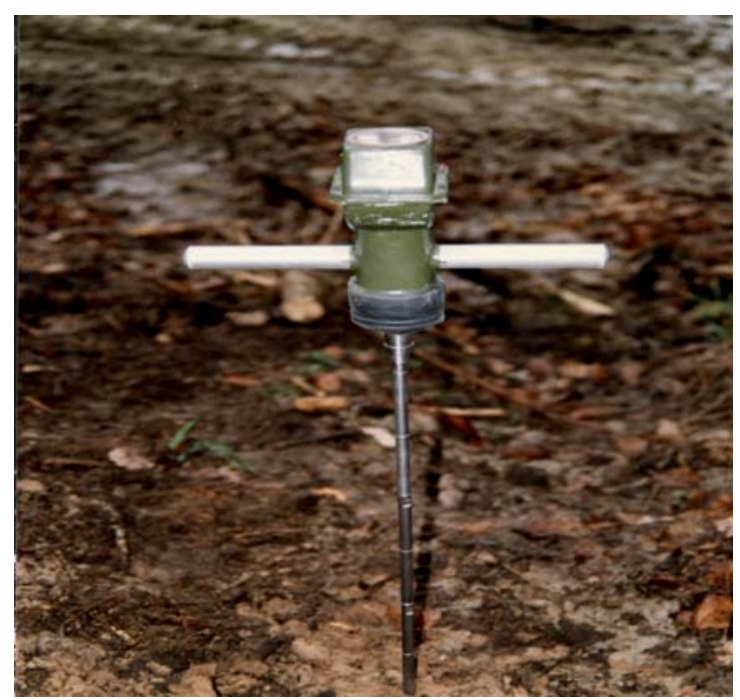

Fig. 3 Portable penetrometer FARNELL.

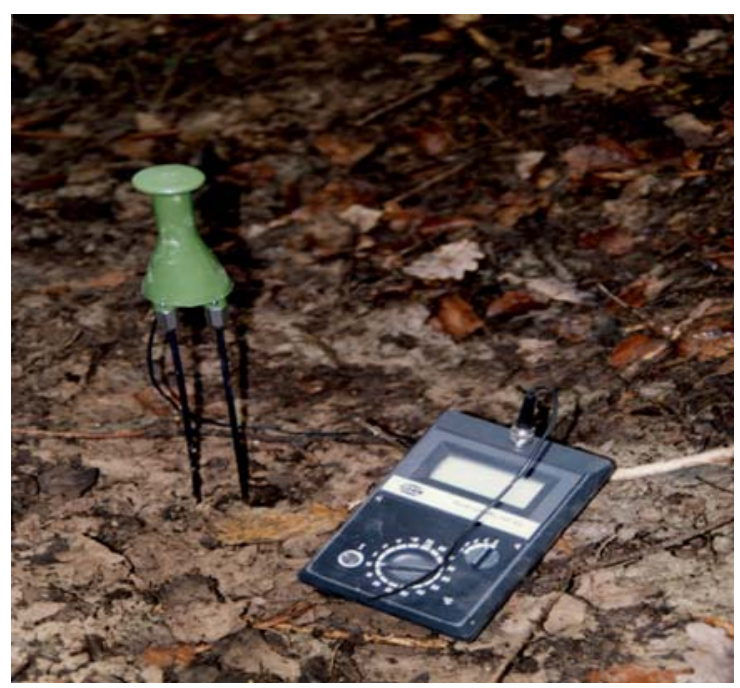

Fig. 4 Portable hygrometer GANN.

\subsection{Method}

From the analysis and the elaboration of the elements of the forest service in Grevena, it is appeared the round wood which was skidded with various means.

With the help of the district's geological map, the native stones or the geological constructions of the forest cluster were defined; however, the researching clusters were determined by the administrative map (Cluster 4e: pyrigen stones, like peridotite, gabbros and dolerite; Cluster 13h: Flysch; Cluster 25a: Sedimentary stones).

Through the proper sample and with the help of the portable hygrometer, the moisture (gravitational, capillary and hygroscopic water) of the natural soil in the searching clusters was measured. However, its resistance in depth of $17 \mathrm{~cm}$ was measured with the portable penetrometer FARNELL, in the same places. This was repeated in different periods, just as spring, summer and autumn of the year 2008.

During the performance of the wood's skidding works with a variety of means, the following were measured:

- The pass ability of soil, in connection with its resistance in $\mathrm{CBR} \%$ and its moisture;

- The pressure caused by the machine's movement in the natural soil (transposition's passing);

- The damages caused by the wood skidding means in the tree's of the remaining stand.

For better determination of the size of damages in $\mathrm{cm}^{2}$ in the standing trees, the damages have been classified into three classes (Table 1).

\section{Results and Discussion}

The results from the analysis and the elaboration of the elements are the following.

Table 1 Size of damage in $\mathrm{cm}^{2}$ in classes A, B and C.

\begin{tabular}{ll}
\hline Classes & Size of damage in $\mathrm{cm}^{2}$ \\
\hline A & $0-10$ \\
B & $11-100$ \\
C & $>100$ \\
\hline
\end{tabular}




\subsection{Wood's Skidding Means}

From the elements of the forest service in Grevena, it is appeared the round wood which was skidded with various means. The results are shown in Figs. 5 and 6.

\subsection{Resistance of Natural Soil in Connection with the} Included Moisture and the Pass Ability of Soil

By the help of the portable hygrometer and the penetrometer, the moisture of natural soil and its resistance were measured in $\mathrm{CBR} \%$ at the same places.

In Figs. 7-9, they show the connection between the resistance of the soil and the contained moisture (depth $17 \mathrm{~cm}$ ), in the area of flysch, pyrigen petrifications and sedimentary petrifications, respectively.

In Fig. 10, according to Erdas [8], it shows the connection between the pass ability of soil and its resistance in $\mathrm{CBR} \%$.

The resistance of the natural soil is greater than 3 CBR\% at a depth of $17 \mathrm{~cm}$ with the moisture of $45 \%$,

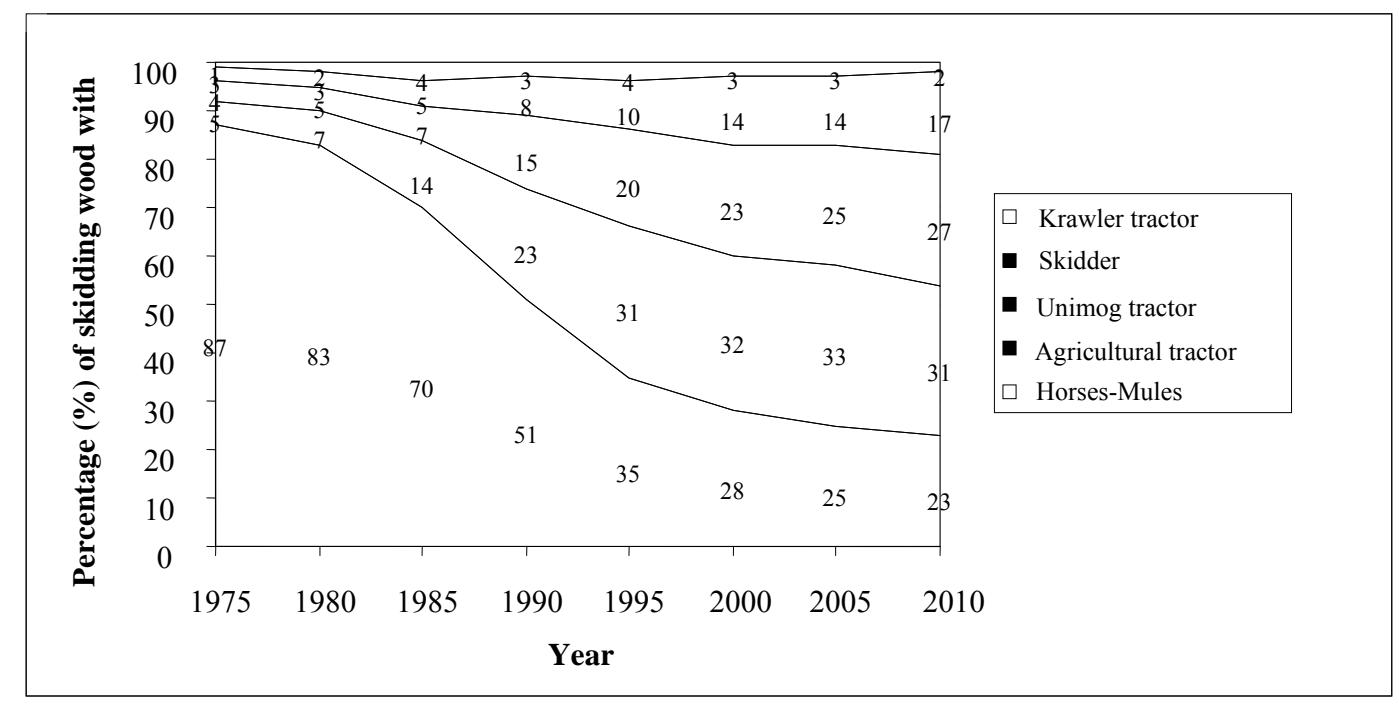

Fig. 5 Round wood's skidding means in Greece.

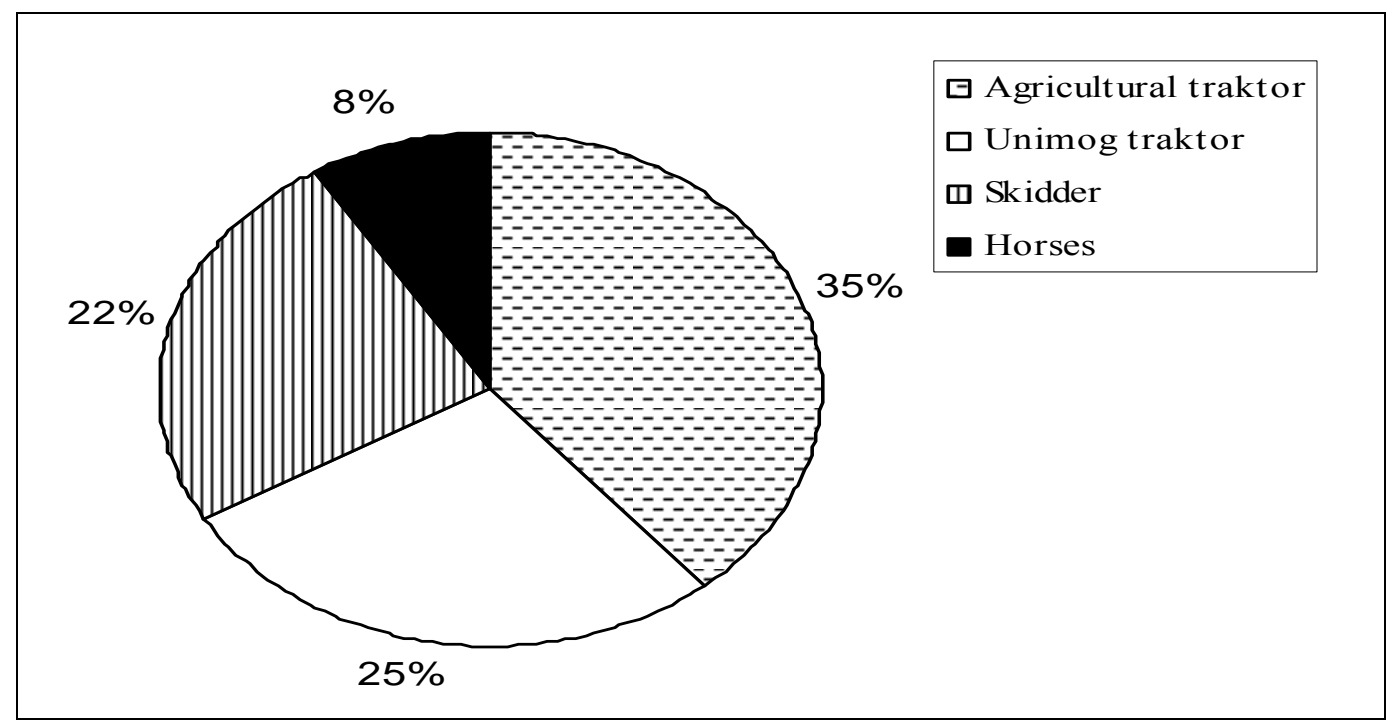

Fig. 6 Round wood's skidding means in the research area in the year 2008. 


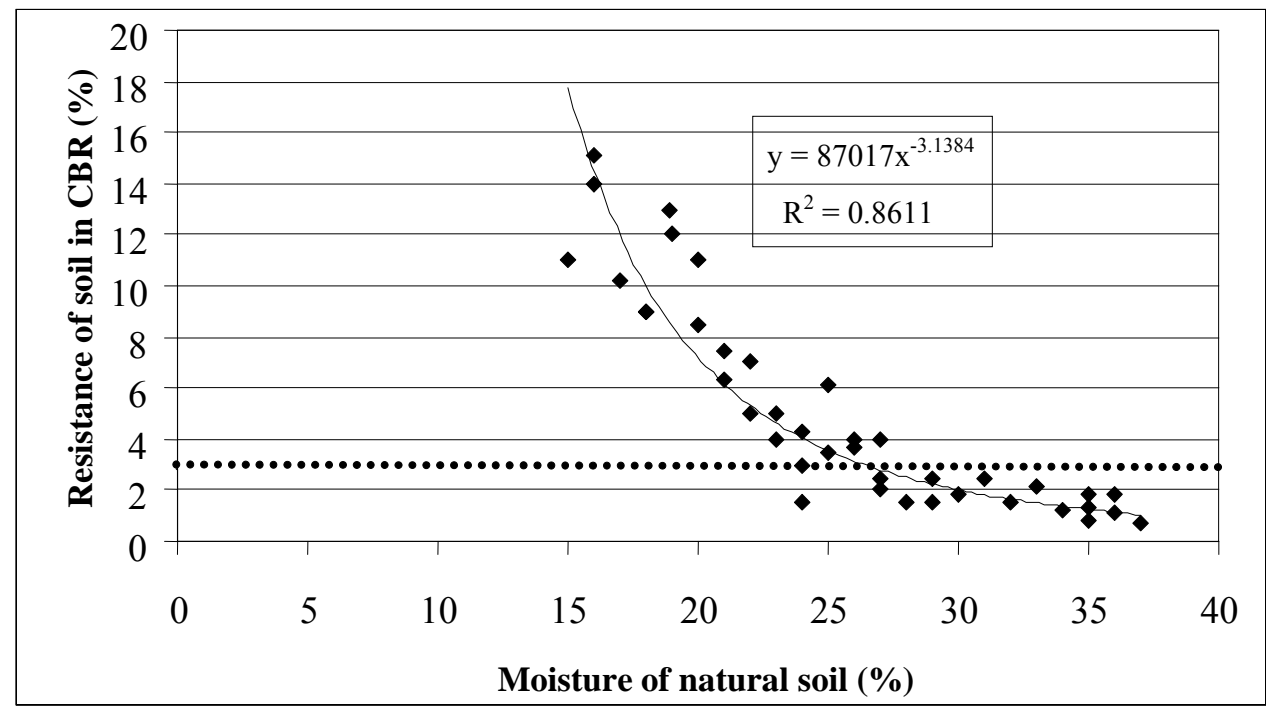

Fig. 7 Resistance of soil in CBR\% in connection with the moisture of it in the area of flysch.

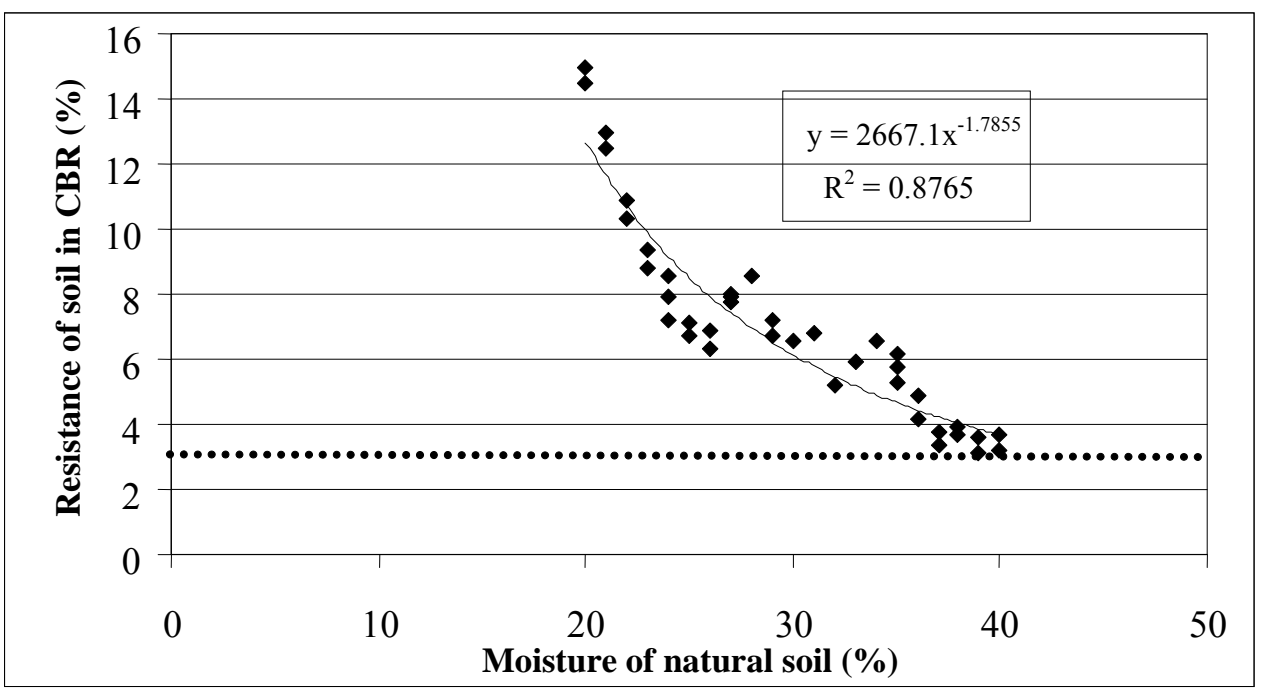

Fig. 8 Resistance of soil in CBR\% in connection with the moisture of it in the area of pyrigen petrifications.

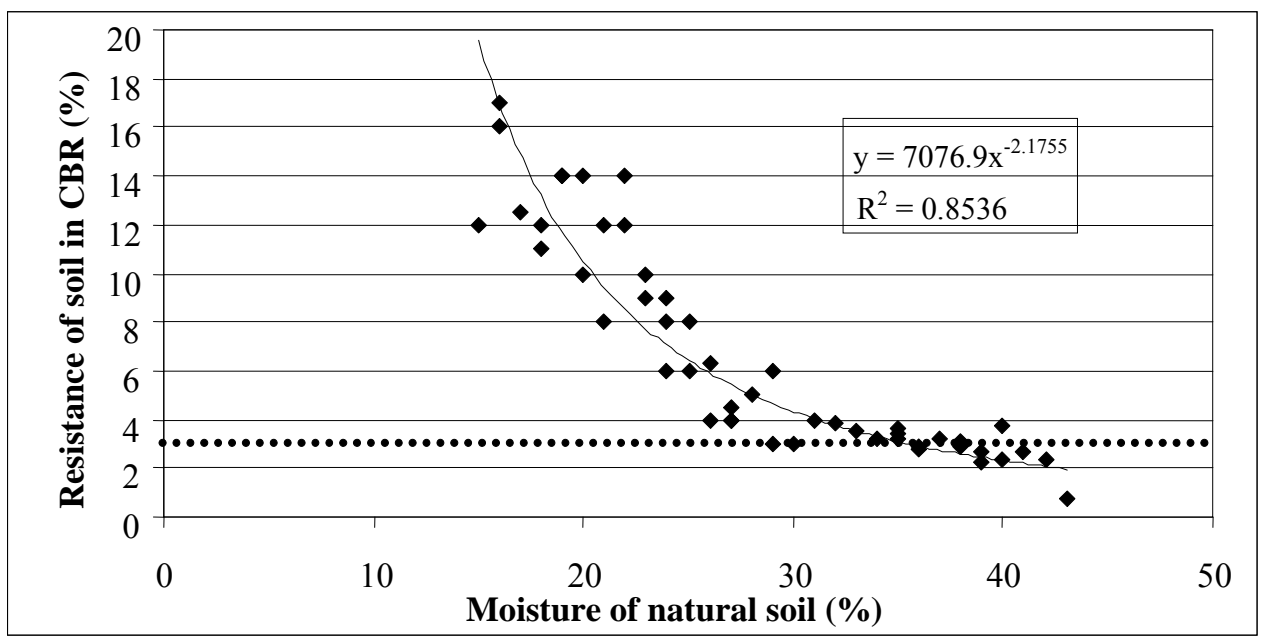

Fig. 9 Resistance of soil in CBR\% in connection with the moisture of it in the area of sedimentary petrifications. 


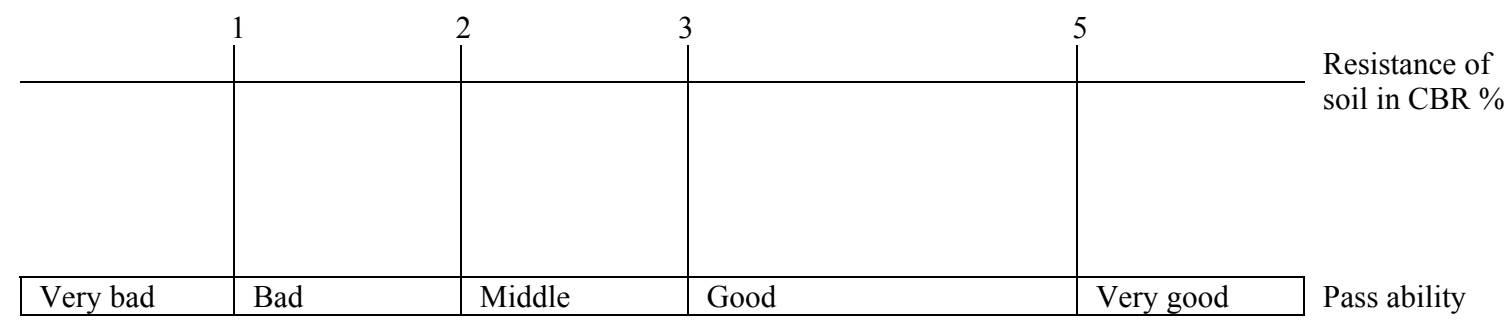

Fig. 10 Connection between the pass ability of soil and its resistance in CBR\%.

$35 \%$ and $26 \%$ in the areas of pyrigen petrifications, sedimentary petrfications and flysch correspondingly.

3.3 Tires Pressure to the Soil and the Pass Ability of Soil

According to technical data of different kinds of tractors, it can calculate the pressure of tires that exerted to the soil during the wood skidding procedure (Table 2 and Fig. 11).

The pressure of the tires, which can be used as a factor for the definition of the soil pass ability, must not surpass the limit of $50 \mathrm{kPa}[9,10]$.

The surface of the soil burst from the tires of the tractors and the powers of detachment are resulted. The detached surface moves side by side with the soil surface. This break of the upper layer of the soil may result in a slippery stratum and in the soil erosion [11].

As far as the damage in the roots is concerned, a division must be done between those caused in the slender root system (diameter less than $2 \mathrm{~mm}$ ) and the ones in the central root. The slender roots which suffer from damages are rapidly reproduced according to the remarks of Wilcox and almost after 20 to 30 days they produce new roots near the wounded one [12]. However, the damages of the central root are the most important.

In 1991, Schlaghamersky [13] mentioned that the loss in growth of the trees were near the tires of the machines, amounts to $6 \%$ till $17 \%$ at interval of 5 to 16 years.

Table 2 Technical data of the tractors in the wood skidding and calculation of the pressure exerted to the soil.

\begin{tabular}{|c|c|c|c|c|}
\hline \multirow{2}{*}{\multicolumn{2}{|c|}{$\begin{array}{ll} & \text { Forest tractor } \\
\text { Technical data of the tractors in the wood (Skidder) } \\
\text { skidding and pressure exerted to the ground } & \text { Franklin } \\
& 132 \mathrm{AXL}\end{array}$}} & \multicolumn{2}{|c|}{ Agricultural tractor } & \multirow[b]{2}{*}{$\begin{array}{l}\text { Tractor } \\
\text { Unimog } \\
\text { U } 406\end{array}$} \\
\hline & & $\begin{array}{l}\text { Steyr } \\
\text { M 9094a F }\end{array}$ & $\begin{array}{l}\text { Universal } \\
643 \text { DT }\end{array}$ & \\
\hline Weight (kg) & 6.822 & 6.180 & 3.010 & 3.260 \\
\hline \multicolumn{5}{|l|}{ Weight distribution $(\mathrm{kg})$} \\
\hline front: & $60 \%$ & $41 \%$ & $33 \%$ & $60 \%$ \\
\hline rear: & $40 \%$ & $59 \%$ & $67 \%$ & $40 \%$ \\
\hline Tire width $b(\mathrm{~cm})$ & 46 & $\begin{array}{l}\text { front: } 48 \\
\quad \text { rear: } 57\end{array}$ & $\begin{array}{l}\text { front: } 27 \\
\quad \text { rear: } 47\end{array}$ & 33 \\
\hline Tire diameter $d(\mathrm{~cm})$ & 142 & $\begin{array}{l}\text { front: } 124 \\
\quad \text { rear: } 164\end{array}$ & $\begin{array}{l}\text { front: } 80 \\
\quad \text { rear: } 120\end{array}$ & 96 \\
\hline Tire pressure (bar) & 1.7 & 1.8 & 2.1 & 2.2 \\
\hline Width tractor $(\mathrm{cm})$ & 235 & 228 & 188 & 190 \\
\hline Horsepower (PS/U/min) & $80 / 2500$ & $68 / 2500$ & $65 / 2400$ & $65 / 2550$ \\
\hline Clearance $(\mathrm{cm})$ & 46 & 42.5 & 30 & 32 \\
\hline Load volume $\left(\mathrm{m}^{3}\right)$ & 2.35 & 1.66 & 1.26 & 1.52 \\
\hline Load weight (kg) & 1.293 & 913 & 693 & 836 \\
\hline \multicolumn{5}{|l|}{ Contact surface $(d / 2) \times b\left(\mathrm{~cm}^{2}\right)$} \\
\hline front: & 3.266 & 2.976 & 1.080 & 1.584 \\
\hline rear: & 3.266 & 4.674 & 2.820 & 1.584 \\
\hline \multicolumn{5}{|l|}{ Ground pressure $\left(\mathrm{kg} / \mathrm{cm}^{2}\right.$ or $\left.\mathrm{kPa}\right)$} \\
\hline front: & 0.63 & 0.43 & 0.46 & 0.62 \\
\hline rear: & 0.52 & 0.44 & 0.48 & 0.54 \\
\hline
\end{tabular}




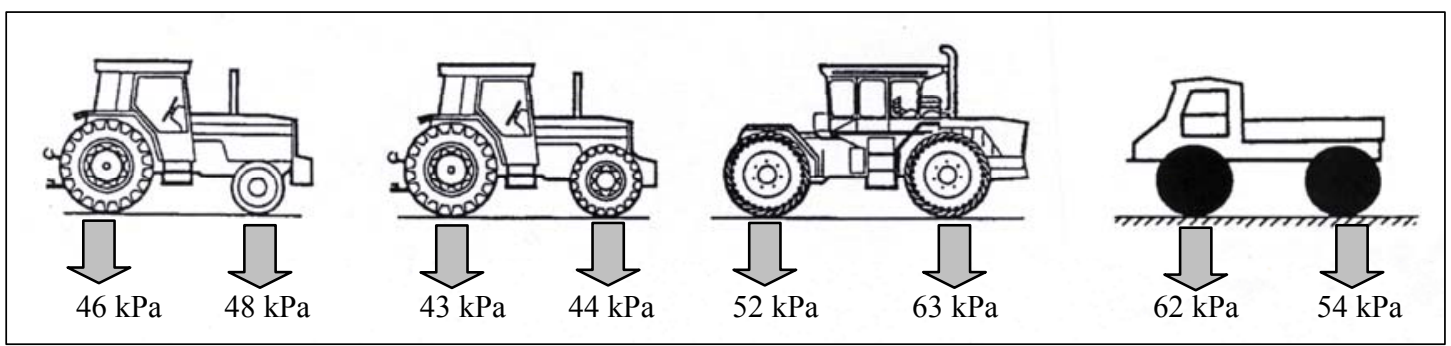

Fig. 11 Pressure of different kinds of tractors in the soil during the wood's skidding.

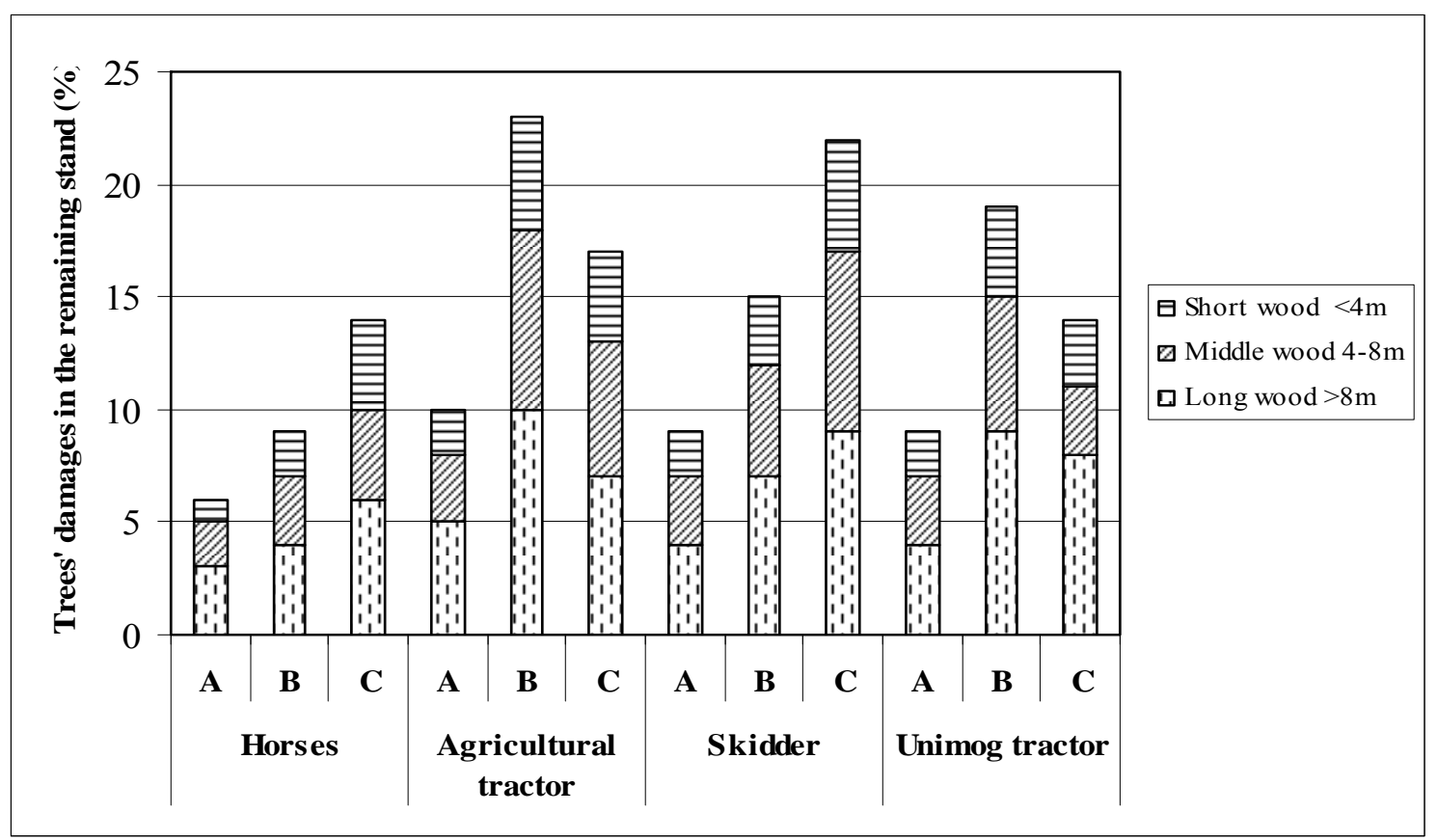

Fig. 12 Classes of damages to the trees in the remaining stand, in connection with the means of woods skidding and the length of wood.

\subsection{Damages to the Trees of the Remaining Stand}

Injuries or breaks of standing trees constitute a remarkable group of negative results of the wood skidding means.

The injured trees are subject to secondary attacks (fungus, insects). The most important damages are taking place to the root system and the trunks in height till $1 \mathrm{~m}$, but they are mainly related to trunk peeling [14].

The percentage of trees suffering from damages because of the movement of various wood skidding means in the researching area is shown in Fig. 12.

\section{Conclusions and Proposals}

According to the results of the research, the following conclusions were reached:

(1) The soil resistance decreases because of the increase of the contained moisture. The resistance of the soil in is satisfactory $(\mathrm{CBR} \%>3)$, in the areas of pyrigen petrification, sedimentary petrfications and flysch when the moisture of the soil is less than $45 \%$, $35 \%$ and $26.4 \%$ correspondingly;

(2) The pressure that tires of tractors exert in the soil is for the agricultural tractor $44-48$ and $43-46 \mathrm{kPa}$, for the forest tractor FRANKLIN, 52 and $63 \mathrm{kPa}$, but as for the tractor Unimog 62 and $54 \mathrm{kPa}$, for the front and the back wheel correspondingly;

(3) The trees' percentage suffering from damages amounts to $6 \%-13 \%$ during the woods skidding with animals (horses), 10\%-23\% for the wood's skidding with agricultural tractor, $9 \%-22 \%$ with forest tractor 
FRANKLIN and between $9 \%$ and $19 \%$ with tractor Unimog. In the middle-European forest bibliography [15] these limits are between $5 \%$ and $10 \%$. A Finland system of insuring quality mentions a percentage of damages smaller than $5 \%$ [16].

According to the above, the following measures are suggested:

(1) The movement of the tractors must not be permitted, when the moisture of the soil surpasses $26 \%$, $35 \%$ and $45 \%$ correspondingly in flysch, pyrigen petrifications and sedimentary area's soils, in order to avoid the damages to the soil;

(2) The tractors, during the wood skidding works especially in soils of low resistance, must be reinforced with broad tires in order to reduce the soil pressure [17];

(3) The damages caused by the wood skidding means to the remaining stand can be reduced and stay within limits. This can be obtained by better organization of the work, education of the tractors' operators and selection of the right machines in each case.

\section{References}

[1] P. Efthymiou, The principles of multidimensional optimization of harvesting systems, Schweizeriche Zeitschrift für Forstwesen 146 (6) (1999) 457-470.

[2] H. Heinimann, Silviculture and forest technique-from the linear to the integrated way of thought, introductions for the opening-up of forest and the forest ergonomics, in: Forest Year-Book for the Emeritus Procedure of Professor Anton Trzesniowski, Soil Science University, Vol. 8, 1998, pp. 27-35.

[3] H. Heinimann, Forest technique compatible to the environment as a precondition for environment-friendly forestry, Forst und Holz 51 (9) (1996) 299-310.

[4] R. Ulrich, Environment-friendly application of forest technique, Decrease of damages to forest ecosystems, in: 34th International Symposium "Mechanization of Forest Work" FORMEC, Poland, 2000, pp. 74-81.

[5] J. Nerunda, Ecological consequences from the usage of general purpose tractors in the wood skidding, in: 34th International Symposium "Mechanization of Forest
Work" FORMEC, Poland, 2000, pp. 62-67.

[6] E. Karagiannis, P. Kararizos, Ecological consequences of wood skidding mechanization works in Greece, in: 35th International Symposium (FORMEC 2001), Czech Republic, pp. 97-107.

[7] Google Website, 2009, http://earth.google.com.

[8] O. Erdas, Soil mechanics problems during passability, the resistance and the wood skidding on forest soils of mid-land (Mesochora) in Switzerland, Ph.D. Thesis, No. 5830, FTU (Federal Technical University), Switzerland, 1976.

[9] I. Wästerlund, Torque distribution in a forwarder with mechanical 8WD soil mechanics in forestry, in: Seminar on the Impact of Mechanization of Forest Operations on the Soil, Belgium, 1989.

[10] D. Matthies, Perspectives of physico-mechanic protection of soil in forestry, in: Year-Book of the School of Forest Science of Munich University and the Institute of Forest Research in Bavaria, No. 166, 1997, pp. 34-47.

[11] P. Abeels, Stress on the soil exerted by forest vehicles and machinery, in: Seminar on the Impact of Mechanization of Forest Operations on the Soil, Belgium, 1989.

[12] R. Hofmann, Soil damages during the application of forest machinery (research of clay-sandy soils for their passability in moisture condition during the spring season), Ph.D. Thesis, Albert-Ludwig University, Freiburg, 1989, p. 140.

[13] A. Schlaghamersky, Description of research plans for the development of methods and simple appliances to calculate the resistance of surface forest soils in order to minimize the damages on the soil and rooting system during the application of wood skidding and harvesting, Forestry Department, Technological Educational Institute, Gottingen, 1991, p. 88.

[14] T. Moskalik, J. Sadowski, Effect of wood harvesting and skidding machinery on forest soils and on the remaining stand, in: 34th International Symposium "Mechanization of Forest Work" FORMEC, Poland, 2000, pp. 74-81.

[15] H. Mayer, E. Ott, Mountainous Silviculture, Forest Protection and Cultivation, Contribution to the Landscape Ecology and the Environmental Protection, 2nd ed., Stuttgart, 1991, p. 587.

[16] E. Kaupilla, Requirements set for harvesting quality after yhinning, and evaluation and measurement of harvesting quality, University of Helsinki, Helsinki, 1991, p. 25.

[17] F. Nipkow, Advantages of wide-rim tires for skidders in forest soils with small resistance, Forstw. Cbl. 102 (1983) 126-142. 